\title{
INCREASING THE EFFICIENCY OF HEAT LOAD CONTROL IN CENTALIZED HEATING NETWORKS
}

\author{
Alexander Shkarovskiy ${ }^{1,2 *}$, Anatolii Kolienko ${ }^{3}$, Vitalii Turchenko³ \\ 1Saint Petersburg State University of Architecture and Civil Engineering \\ Vtoraja Krasnoarmeyskaya st., 4, Saint Petersburg, Russia \\ ${ }^{2}$ Koszalin University of Technology \\ Sniadeckich St., 2, Koszalin, Poland \\ ${ }^{3}$ National University "Yuri Kondratyuk Poltava Polytechnic" \\ Piershotravnevyj Ave., 24, Poltava, Ukraine \\ *Corresponding author: szkarowski@mail.ru
}

\begin{abstract}
The paper presents the results of studies aimed to increase the efficiency of centralized heating networks by improving heat supply control at the plant and at the local level. With this in view, we considered issues of choosing the optimal heat supply schedule and its influence on the efficiency of heat generation, transportation and use, as well as the influence of the heat carrier temperature on heat losses at the corner of the temperature curve. We also studied the influence of the heat carrier temperature in the return pipe of heating networks on the operation of heat generators by using various control methods. Another issue considered in the course of the study was the issue of ensuring the hydraulic and thermal stability of heating networks and heating systems connected to them by using the combined control method. The methodology of the study was based on the analysis of heat balance equations for the steady-state operation of a complex including a heating network and a building's heating system. As a result, we obtained relationships that make it possible to determine the variation in the heat carrier flow rate and temperature depending on the heat load, as well as the reduction in energy consumption for heat carrier transportation. Recommendations were developed for the introduction of combined heat load control. A scheme for the reconstruction of central heat stations is proposed. The scientific and practical results of the study can be used to prevent significant heat losses, ensure optimal operation of heating networks, heat generators, and heating systems, reduce energy consumption, and increase the overall efficiency of centralized heating networks.
\end{abstract}

\section{Keywords}

Heat supply, centralized heating networks, energy saving, efficiency, heat load control.

\section{Introduction}

Providing high-quality heat supply while ensuring energy-efficient heat generation, supply and transportation in centralized heating networks (CHNs) is a complex task. The main focus is usually on the efficient use of fuel in heat sources and heat saving directly in consumer systems (Kultyaev, 2017). However, heat carrier supply and transportation as well as the subsequent transformation of heat carrier parameters at consumer connection points account for a significant part of energy losses (Rafalskaya et al., 2019). The efficiency of this complex process is largely determined by the selected methods of $\mathrm{CHN}$ operation control at all stages (Magnusson, 2011). Heat supply control at the plant shall be recognized as a key link in this chain (Szkarowski, 2019).

Such control shall ensure the high energy efficiency of $\mathrm{CHN}$ operation and improve specific indicators of heat generation and supply. However, these tasks are subordinated to a more comprehensive goal of maintaining particular temperature conditions in buildings at any changes in the external temperature, air infiltration and heat development (Rafalskaya et al., 2018).

Energy losses caused by the low efficiency of control systems during heat generation, transportation and supply in $\mathrm{CHNs}$ pose a serious problem. This issue is the main $\mathrm{CHN}$ disadvantage when comparing independent and centralized heating networks (Chicherin, 2018).

It is well known that central heat supply quality control at the heat source has a number of drawbacks (Sokolov, 1982). As for local control, energy losses are significant as well, including due to the imperfect design of consumer connection points in buildings and devices for heating unit control.

As a rule, CHN control at the heat source and local control at the heat consumer are considered separately both from the technical and organizational point of view (Chicherin et al., 2018; Cui et al. 2014; Pieper et al., 2017). However, it is obvious that they are bound just as closely (by the common goal, which is to ensure particular temperature conditions in buildings) as the interrelated processes of heat 
generation, transportation and supply in $\mathrm{CHNs}$. This paper is the first to comprehensively consider the influence of individual stages of heat transformation on the overall efficiency of $\mathrm{CHN}$ operation.

\section{Analysis of the current state of the issue}

The principles of central and local CHN control are in conflict with each other. Issues of improving the energy efficiency of buildings are usually solved before the issues of $\mathrm{CHN}$ reconstruction, which are addressed only as a result of reforms in the field of energy efficiency of buildings as heat consumers.

Thermal modernization of buildings reduces the design heat load for heating and hot water supply. Thus, the gap between the rated heat generator capacity and the connected heat load, which is detrimental to the heat source, increases. Equipment of some consumers connected to the $\mathrm{CHN}$ heating network with automated individual heat stations (IHSs) including mixing units results in consumers with different requirements for pressure at the inlet. Differential pressure controls at the inlet contribute to the hydraulic and thermal deregulation of the heating network and disrupt heat supply in buildings without automated IHSs. Automatic local control of the flow rate of the heat carrier, entering end-user heating systems, makes it impossible to ensure adequate central heat supply control in boiler houses. The attempts to reduce the heat supply temperature and switch to a low-temperature schedule typical for $4^{\text {th }}$ generation $\mathrm{CHNs}$ introduce problems with heat transfer from heating units at the consumer side. In fact, there are many examples of such mutual influence, which is not always useful (Sharapov et al., 2010).

In this regard, the joint consideration of central and local control suggested in the paper seems relevant since it has not been resolved yet at a serious level. The solutions proposed below will likely increase the efficiency of existing $\mathrm{CHNs}$ when switching to more efficient alternatives.

The issue of design temperature conditions in a heating network shall be considered separately. As for existing CHNs, a typical approach involves the following: maintaining (if possible) a higher heat carrier temperature in the supply pipe of the heating network and a higher water temperature difference in the supply $\left(\boldsymbol{\tau}_{1}\right)$ and return $\left(\boldsymbol{\tau}_{2}\right)$ pipes (Sharapov and Rotov, 2007; Sokolov, 1982). An increase in temperature difference will make it possible to reduce the heat carrier flow rate and the hydraulic resistance of the network, as well as the diameter of the pipes. The reduced pipe diameter means less volume of water and smaller leakage areas. All this will reduce water losses as well as the cost of heat carrier pumping and make-up water treatment.

To maintain a high-temperature schedule of heat supply, technically sound mixing units are required at the inlet to buildings, which is not always the case. In this case, low-temperature modes close to the heating schedule are preferable.

The transition to a lower temperature in the supply pipe has a number of advantages. Foreign $4^{\text {th }}$ generation $\mathrm{CHNs}$ are oriented towards lower temperature schedules of heat supply (Bhatt and Verma, 2015; Lund et al., 2018). The corresponding European standards are aimed at the same (European Parliament and Council, 2018).

\section{Subject, tasks, and methods}

Central heat supply quality control (by changing the heat carrier temperature) is the most common method in Russian heating networks. However, this method has a significant disadvantage: inefficient control at the corner (breakpoint) of the temperature curve when heat is used both for heating and hot water supply. From this point on, it is impossible to control heat supply by changing the heat carrier temperature. In this case, the heat carrier temperature in the supply pipe is kept constant $\left(65^{\circ} \mathrm{C}\right)$ to ensure a hot water temperature of at least $60{ }^{\circ} \mathrm{C}$

We already demonstrated that operation in this period is associated with excessive heating (overheating of premises) and significant inefficient heat losses (Szkarowski et al., 2016). In this case, a decrease in the network heat carrier temperature leads to a decrease in the external temperature, which results in the mentioned corner of the temperature curve, an increase in the duration of system operation in the excessive heating mode, and an increase in inefficient heat losses. Fig. 1 shows this relationship for the following climatic parameters: external design temperature $\boldsymbol{t}_{e}^{d}=-23{ }^{\circ} \mathrm{C}$ at the temperature at the beginning of the heating season $t_{e}^{h p b}=+8{ }^{\circ} \mathrm{C}$

As can be seen, an increase in the design parameters of the heat carrier from 95 to $150{ }^{\circ} \mathrm{C}$ increases the external temperature from 0 to $+3.5^{\circ} \mathrm{C}$ (at which it will be necessary to stop central heat supply quality control), i.e., shifts the corner point to the end of the heating season. The duration of this unfavorable period is reduced from 3600 to 1100 hours. Thus, the annual inefficient heat losses, corresponding to the corner of the temperature curve, decrease with an increase in the design heating water temperature in heating networks.

Fig. 2 shows how the impossibility to carry out quality control affects additional heat losses during heat carrier transportation, corresponding to the corner of the temperature curve, under the same climatic conditions. It follows from the diagram that the increase in these losses is most significant at a heat carrier temperature of $115-95^{\circ} \mathrm{C}$, i.e., at low operating parameters of the heating network.

However, negative economic consequences of high-temperature modes of the heating network should be mentioned as well. For instance, as the difference between the temperatures of the network heat carrier and the ground increases, heat losses 
through heat insulation increase as well. For the selected climatic conditions, this can be represented by the relationship shown in Fig. 3 .

Another reason for an ambiguous assessment of high-temperature modes is the influence of the heat carrier temperature on the performance efficiency and thermodynamic efficiency of heat generators of $\mathrm{CHN}$ sources. Higher heat carrier temperatures mean a higher temperature of flue gases and an increase in corresponding heat losses in the heat balance of the boiler. The average temperature of flue gases in the case of standard (non-condensing) hot water boilers in $\mathrm{CHNs}$ is $160-180{ }^{\circ} \mathrm{C}$ and often even higher. At such a temperature, heat losses with flue gases $\left(\mathbf{q}_{2}\right.$ value in the heat balance of the boiler) can account for up to $9-11 \%$ of the heat potential of the fuel. This reduces the performance efficiency of the system as a whole.

These losses can be reduced significantly by lowering the temperature of flue gases. A decrease in their temperature from 200 to $100{ }^{\circ} \mathrm{C}$ makes it possible to reduce $\mathbf{q}_{2}$ by $5 \%$. Cooling to $60{ }^{\circ} \mathrm{C}$ will ensure more than $7 \%$ saving.

An even more effective method of increasing the efficiency of fuel use in CHNs is the condensation of water vapor from the combustion products. In this case, flue gases shall be cooled to $55-56^{\circ} \mathrm{C}$ (dew point). In addition to reducing physical heat losses $\mathbf{q}_{2}$, each kilogram of condensed moisture makes it possible to return approx. $2.5 \mathrm{MJ}$ to the heat balance of the boiler.

This could be ensured by the use of condensing boilers. Unfortunately, so far, this task is not feasible in a broad sense. However, it is possible to install condensing heat exchangers at the flue gas ducts. Fig. 4 shows a circuit diagram for the installation of a condensing heat exchanger on the flue gas line of the $\mathrm{CHN}$ boiler house.

In any case, to ensure efficient flue gas heat recovery, a sufficiently low temperature of the heat carrier is required in the return pipe of a heating network. For instance, intensive condensation of water vapor on the heat exchange surface is provided at a temperature of network water in the return pipe not higher than $40-45^{\circ} \mathrm{C}$. This is possible only when switching to a low-temperature heat supply, which, at the first glance, contradicts the results of the above analysis. We cannot hope that an increase in the efficiency of heat sources will compensate for long-term unproductive operation in the mode corresponding to the corner of the temperature curve.

In that respect, a radical solution would be to switch to central flow rate control after the moment

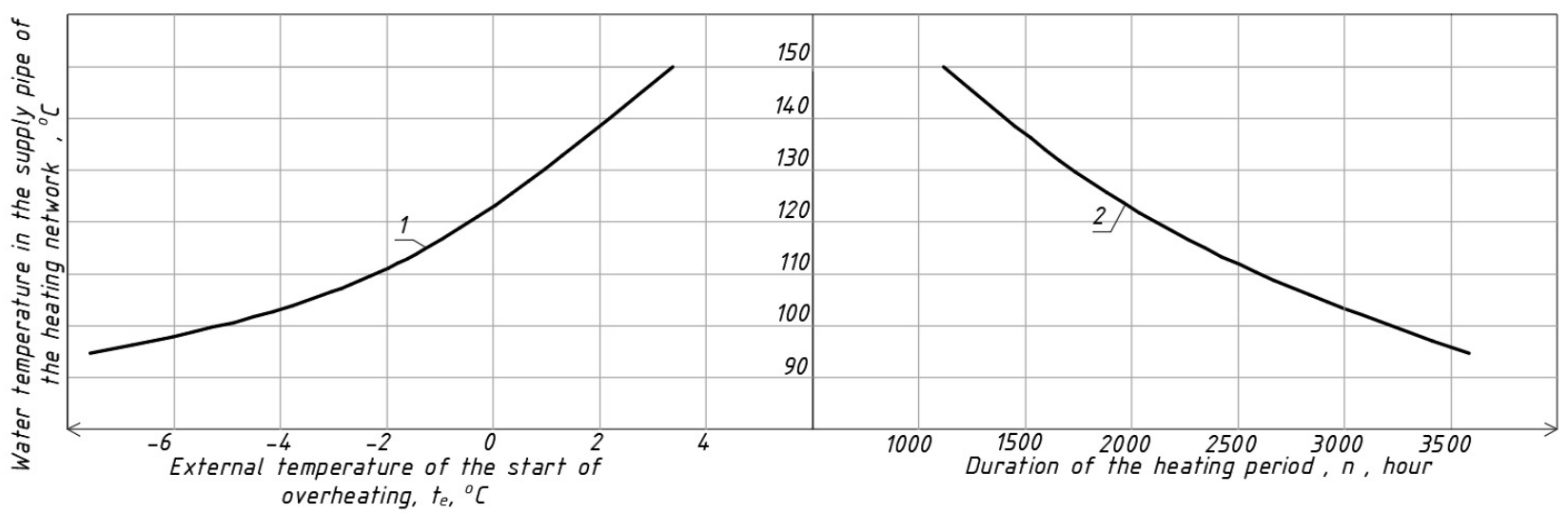

Figure 1. Influence of the design network water temperature on the external temperature, at which excessive heating begins (on the left) and the duration of heating system operation in this mode (on the right) under the selected climatic conditions

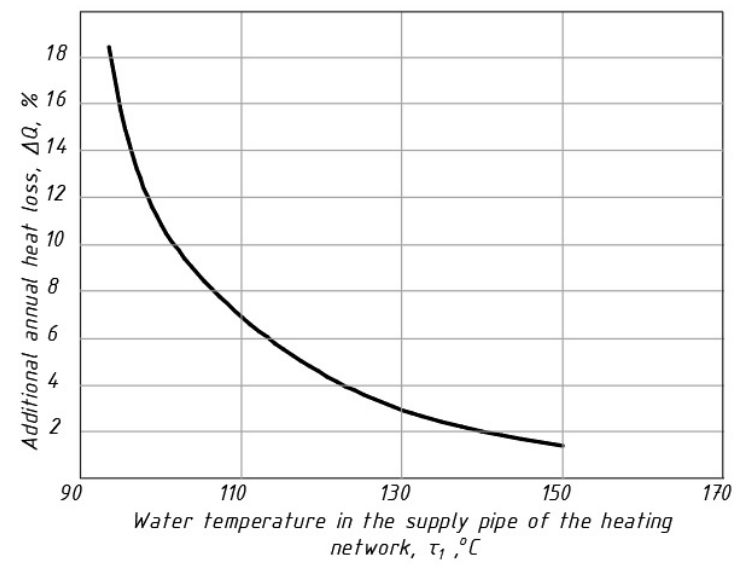

Figure 2. Additional heat losses, corresponding to the corner of the temperature curve, vs. network water temperature 
corresponding to the corner of the temperature curve while introducing quality local control of heating systems. Modern automated heat stations provide control of the heat carrier temperature depending on the external temperature by changing the mixing ratio of network and return water in the admix units of heating systems. This also contributes to a decrease in the heat carrier temperature in the return pipe of heating networks.

However, the number of such heat stations is still insufficient, especially in old built-up areas and in small towns. The lack of controlled mixing units in local systems with a high-temperature schedule of heat supply results in a high heat carrier temperature in the return pipe of heating networks, which reduces the efficiency of fuel use at the heat source.

Thus, the issue of choosing the method of central and local control of $\mathrm{CHNs}$ and temperature schedule of heat supply remains open and depends on a large number of factors. Preliminary consideration of this issue shows that the transition to a lowtemperature schedule of heat supply does not make sense. Without the introduction of condensing boilers or condensing waste heat exchangers and without the transition to central flow rate control of $\mathrm{CHN}$, this will significantly deteriorate the overall performance of the heating network. The reason for that is a significant increase (up to $18 \%$ of the fuel potential) in inefficient heat losses during the period corresponding to the breakpoint of the temperature

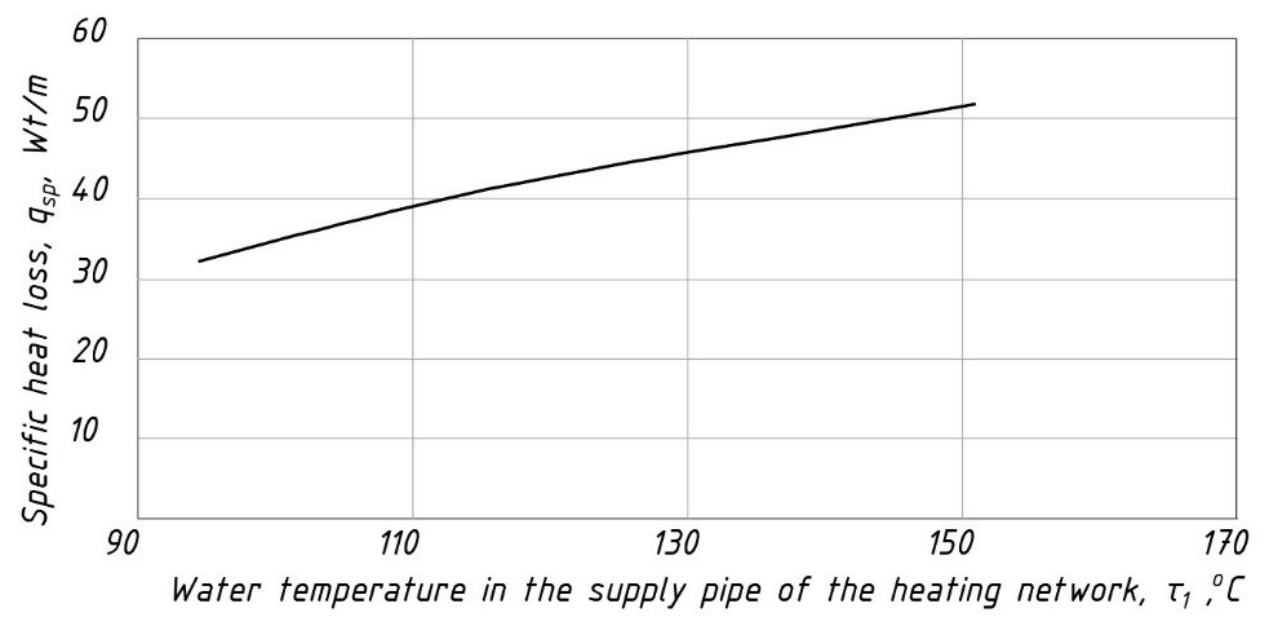

Figure 3. Specific heat losses by heating network pipes vs. network water temperature

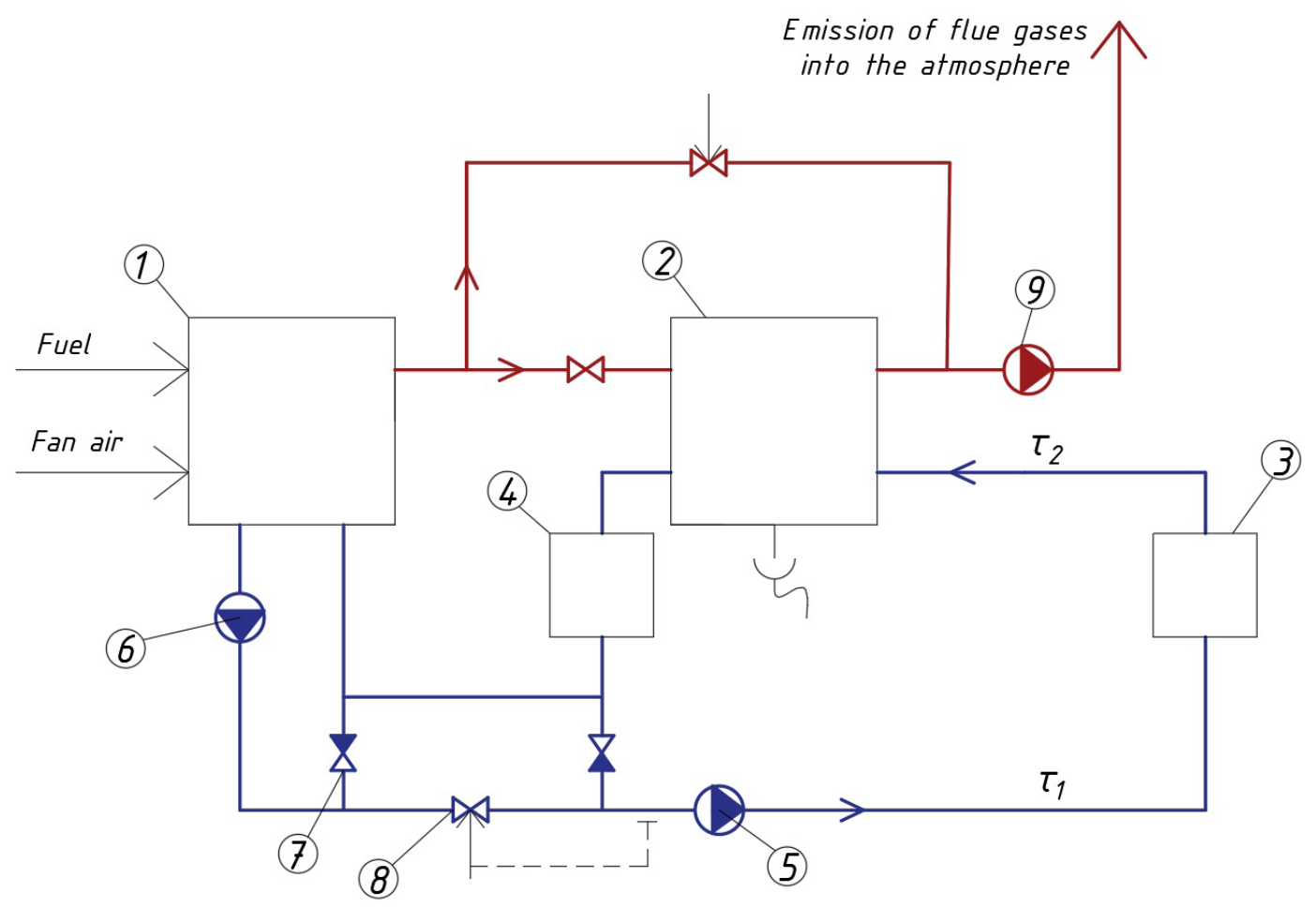

Figure 4. Circuit diagram for combustion products' heat recovery in a condensing heat exchanger: 1 - hot water boiler; 2 - condensing waste heat exchanger; 3 - heat consumer, 4 - calciner, 5 - circulating pump of the heating network, 6 - boiler circuit pump, 7 - check valve, 8 - temperature controller, 9 - flue gas duct 
curve when switching to a low-temperature schedule. In our work, we made an attempt to use modeling methods to develop recommendations for choosing the optimal parameters of CHN operation.

\section{Results and discussion}

Control of heterogeneous heat load can be central (at the heat source) and local (at individual or group consumer connection points). The heat transfer from heating units in heating systems can be controlled by changing:

- the heat carrier temperature in the supply pipe of the heating network $\tau_{1}$;

- the heat carrier temperature at the input to the heating system $\mathbf{t}_{1}$;

- the flow rate of the heat carrier in the heating network for heating $\mathbf{G}_{\boldsymbol{h}}$;

- the flow rate of the heat carrier circulating in the heating system (after the admix unit) $\mathbf{G}_{h s}$.

In this case, a number of the following restrictions shall be observed:

- in case of hot water supply load, the temperature $\tau_{1}$ cannot be lower than that required for hot water heating $\left(65^{\circ} \mathrm{C}\right)$;

- an increase in the flow rate of the network heat carrier for heating $\mathbf{G}_{\boldsymbol{h}}$ is limited by an increase in the hydraulic resistance of the heating network and heating systems as well as network water pressure difference at the inlet to buildings;

- a decrease in the flow rate of the heat carrier in heating systems is limited by a decrease in the hydraulic and thermal stability of end-user heating systems (it is not recommended to reduce the flow rate by less than $60 \%$ of the design values);

- a decrease in the temperature at the input to the heating system $\mathbf{t}_{1}$ is limited by disproportionate changes in the heat transfer from heating units (loss of vertical thermal stability) - up to $40 \%$ on the lower floors compared to the upper ones.

It seems optimal to introduce combined quality and flow rate local control, which has not been applied yet even at modern automated IHSs with control depending on the external temperature (weather control).

Currently, IHSs use quality control by admixing the cooled heat carrier from the heating system to the hot heat carrier from the heating network. The weather control adjusts the mixing ratio so that the temperature $\mathbf{t}_{1}$ would correspond to the current external temperature. In this case, the flow rate of water circulating in the heating system (after the mixing unit) does not change: $\mathbf{G}_{h s}=$ const.

An independent circuit for heating systems' connection to heating networks (through a heat exchanger) and a dependent circuit with a mixing pump are also known. In these cases, it is possible to improve the quality of heating system control through local quality control (Bogoslovsky and Skanavi, 1991).

Finally, when $\mathrm{CHNs}$ operate according to a heating schedule, no mixing units are available at consumer connection points.

In all cases, it is extremely important to maintain the thermal stability of heating systems, which is the task of central control. From this perspective, we considered the main possibilities of increasing the efficiency and quality of heat supply in CHNs.

\section{Consideration of central control specifics \\ Quality and flow rate control}

The classical approach implies that in order to prevent vertical temperature stratification in heating systems, it is necessary, along with changes in the network heat carrier temperature $\tau_{1}$ to change the relative flow rate of water for heating $\boldsymbol{\alpha}_{h}$. This relationship is usually represented in dependence to the relative heat load for heating $\varphi_{h}$ as follows (Logunova and Zorya, 2020):

$$
\alpha_{h}=\varphi_{h}^{n}
$$

where the exponent $\boldsymbol{n}$ is taken equal to 0.33 for twopipe systems and 0.25 for one-pipe systems.

This method is called optimal quality and flow rate control. Earlier, it was difficult to implement it in practice due to issues with smooth control of the network pump rate. Usually, the flow rate of network water changed stepwise several times during the heating season, and at such a flow rate, quality control was carried out. Modern capabilities of pump rpm control make it possible to optimize $\mathrm{CHN}$ operation, thus bringing new life into the principle of quality and flow rate control.

\section{Central flow rate control}

New technical capabilities change our perception of central flow rate control. Usually, it was recommended only after the point corresponding to the corner of the temperature curve but it was related to the issue of network pump rate control mentioned above. Besides, since it was necessary to prevent temperature stratification in heating systems, the possibilities of flow rate control were limited by the permissible value of the relative flow rate of network water for heating $\boldsymbol{\alpha}_{\mathrm{h}}=0.6$.

The rule of flow rate control usually has the following form (Szkarowski, 2019):

$$
\alpha_{\mathrm{h}}=\frac{(0.5+u) \Delta t_{\mathrm{d}} \varphi_{\mathrm{h}}}{\tau_{1}-\delta t_{\mathrm{d}} \varphi_{\mathrm{h}}^{n}-t_{\mathrm{int}}}
$$

where: $\boldsymbol{u}$ is the mixing ratio in the mixing unit of the heating system; $\Delta \boldsymbol{t}_{\boldsymbol{d}}$ is the design water temperature difference in the heating system; $\delta \boldsymbol{t}_{\boldsymbol{d}}$ is the design temperature difference between the heating units and internal air; $\boldsymbol{t}_{\text {int }}$ is the temperature of internal air; $\boldsymbol{n}=0.75-0.8$.

Based on the heat balance equations, using 
an original method, we simulated central flow rate control for various temperature conditions in the heating network. The results are shown in Fig. 5 in the form of the relationship $\alpha_{h}=f\left(\varphi_{h}\right)$.

To ensure optimal heat load control, typical for the average temperature in the heating period (about $50 \%$ of the design value) at a temperature schedule of $115 / 70^{\circ} \mathrm{C}$, the relative flow rate of the heat carrier will be approx. $30 \%$ of the design one. At a load of $20 \%$, typical for the beginning and end of the heating period, the flow rate of the heat carrier will be $10 \%$ of the design value.

With flow rate control, the heat carrier temperature in the supply pipe remains constant throughout the entire control range. This solves the problem of inefficient heat losses during the period corresponding to the breakpoint of the temperature curve and excessive heating in the transition period, which is inevitable in the case of quality control. Besides, a decrease in the flow rate of the network heat carrier will significantly reduce the cost of energy for pumping.

\section{Heat carrier temperature in the return pipe of} the heating network

The calculations performed above do not provide information on the influence of flow rate control on the temperature in the return pipe of the heating network. As shown above, this factor is of key importance for the efficiency of heat generation and the $\mathrm{CHN}$ in general, especially when using condensing heat exchangers.
To solve this issue, the heat balance equations were solved with respect to the temperature in the return pipe of the heating network $\tau_{2}$ for three different methods of central control: quality control (the current case); flow rate control; combined control (quality control up to the corner point and flow rate control after the corner point).

The calculation results are shown in Figs. 6, 7, and 8 in the form of a dependence of the heat carrier temperature in the return pipe and the relative heat load on the external temperature.

The comparative analysis of the calculation results shows the following. With quality control (Fig. 6), the heat carrier temperature in the return pipe for high-temperature schedules only approaches the dew point of water vapor in the combustion products but does not reach it, which does not ensure the efficient operation of the condensing heat exchangers.

When switching to a temperature schedule of $80 / 60^{\circ} \mathrm{C}$, the heat carrier temperature in the return pipe at a heat load of about $84 \%$ of the design one decreases to the dew point. This guarantees the efficient operation of the condensing heat exchangers and a significant increase in the efficiency of the boilers throughout almost the entire heating period. However, such a temperature schedule is rarely used in domestic heating networks.

With combined control (Fig. 7), the heat carrier temperature in the return pipe, required for the efficient operation of the condensing heat

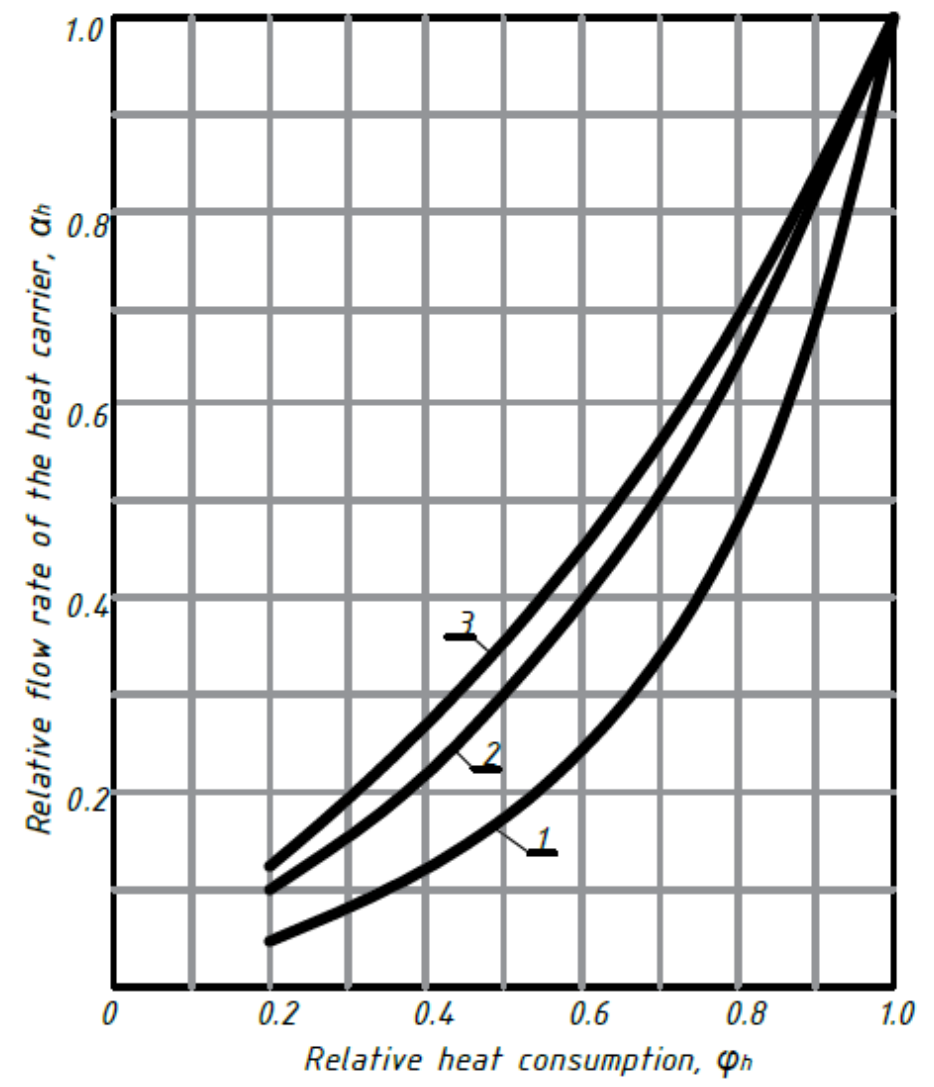

Figure 5. Central flow rate control for various temperature conditions in the heating network: $90 / 70^{\circ} \mathrm{C}(1) ; 115 / 70^{\circ} \mathrm{C}(2) ; 135 / 70^{\circ} \mathrm{C}(3)$ 


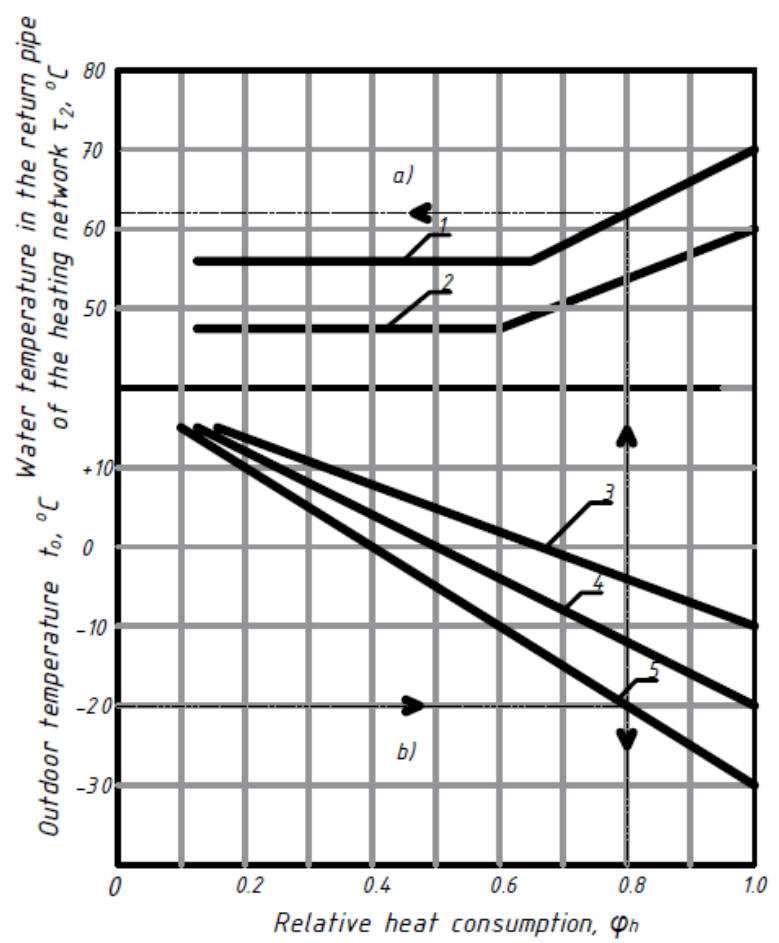

Figure 6. Heat carrier temperature in the return pipe of the heating network (a) and relative heat load for heating (b) vs. external temperature for different temperature schedules of heat supply: $135 / 70{ }^{\circ} \mathrm{C} ; 115 / 70{ }^{\circ} \mathrm{C}$, and $90 / 70{ }^{\circ} \mathrm{C}(1) ; 80 / 60{ }^{\circ} \mathrm{C}$

(2), and different design external temperatures: $-10^{\circ} \mathrm{C}(3) ;-20^{\circ} \mathrm{C}(4) ;-30^{\circ} \mathrm{C}(5)$, with central quality control

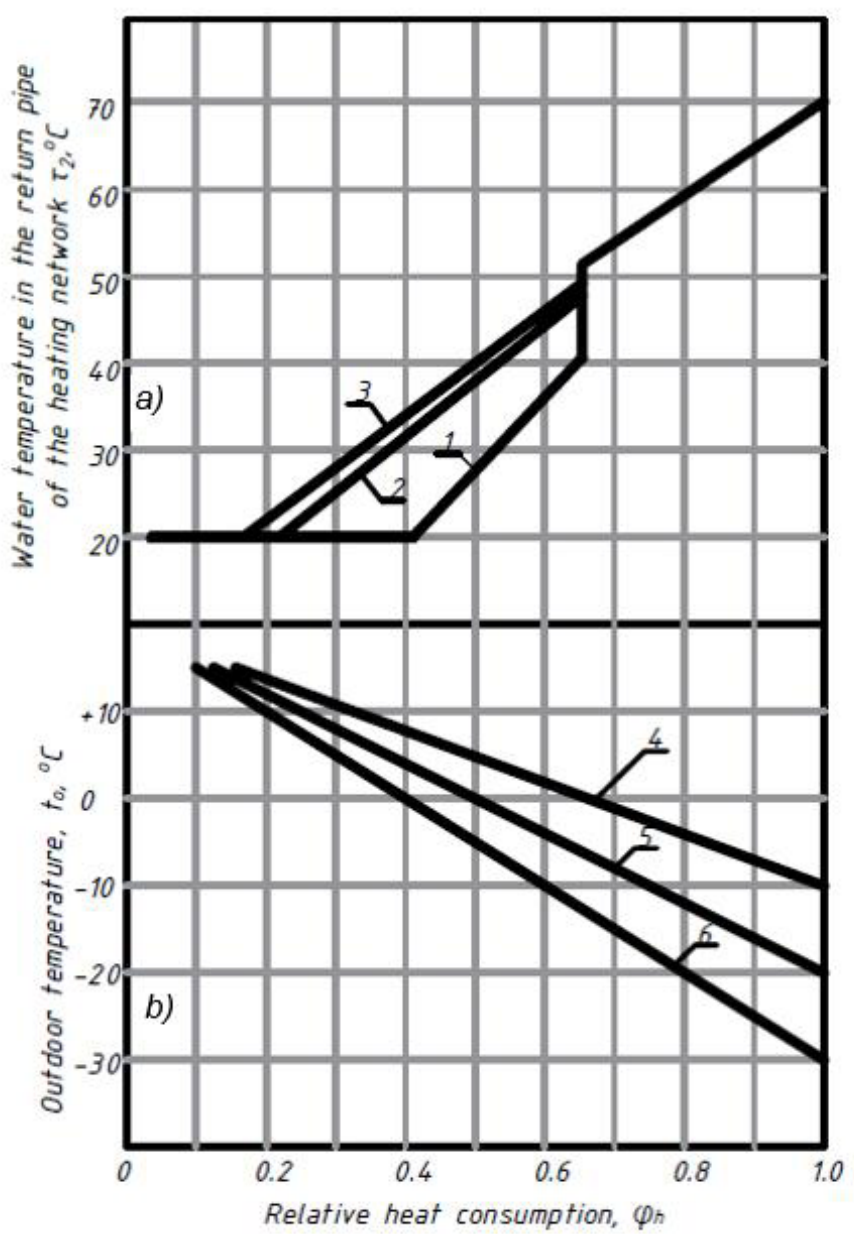

Figure 7. Heat carrier temperature in the return pipe of the heating network (a) and the relative heat load for heating (b) vs. external temperature for different temperature schedules of heat supply: $90 / 70{ }^{\circ} \mathrm{C}(1) ; 115 / 70{ }^{\circ} \mathrm{C}(2) ; 135 / 70{ }^{\circ} \mathrm{C}$

(3), and different design external temperatures: $-10^{\circ} \mathrm{C}(4) ;-20^{\circ} \mathrm{C}(5) ;-30^{\circ} \mathrm{C}(6)$, with combined central control 
exchangers and $\mathrm{CHN}$ in general, is achieved at a heat load below $65-70 \%$ of the design one.

At a load of about $50 \%$, the heat carrier temperature in the return pipe will be approx. $40^{\circ} \mathrm{C}$ even for a temperature schedule of $135 / 70^{\circ} \mathrm{C}$, and with a schedule of $90 / 70^{\circ} \mathrm{C}$, it will drop to $28^{\circ} \mathrm{C}$, which will ensure very high performance efficiency of the condensing heat exchangers.

The transition to central flow rate control of heat supply (Fig. 8) significantly improves the operating conditions of the condensing heat exchangers and convection heating surfaces of the boilers, increases the depth of heat extraction from the combustion products, and increases the efficiency of the heat generators and $\mathrm{CHN}$ in general. This is due to the fact that the temperature in the return pipe of the heating network is significantly reduced. As with combined control, at a load of $50 \%$ of the design one, the heat carrier temperature in the return pipe of the heating network is approx. $40^{\circ} \mathrm{C}$, even for a temperature schedule of $135 / 70^{\circ} \mathrm{C}$. The transition to temperatures above the dew point for this graph occurs only at an increase in the load to $80 \%$ of the design one, which for areas with a design external temperature of $-20^{\circ} \mathrm{C}$ occurs at $-12^{\circ} \mathrm{C}$. Therefore, for most of the heating season, the water temperature in the return pile will be below the dew point, which guarantees the stable operation of the condensing heat exchangers.
Thus, the transition to central flow rate or combined control makes it possible to prevent excessive heating of buildings during the period corresponding to the breakpoint of the temperature curve, preserve the possibility of generating hot water of the required quality, avoid inefficient heat losses, and ensure the high energy efficiency of the CHN. In this case, the use of low-temperature schedules of heat supply is the most acceptable.

Among other advantages of low-temperature schedules of heat supply, the following can be mentioned:

- reduction of heat losses during transportation;

- reduction of the thermal elongation of pipes and, as a result, a simpler design of heating networks and elimination of hazardous expansion joints;

- an increase in the generation of electrical energy at sources with co-generation of heating and power (CHP plants) due to a decrease in pressure at the heat extraction sections of turbines;

- possibility of $\mathrm{CHN}$ operation with alternative and renewable energy sources.

2. Energy consumption for heat carrier pumping

In addition to the advantages mentioned above, flow rate and combined control make it possible to

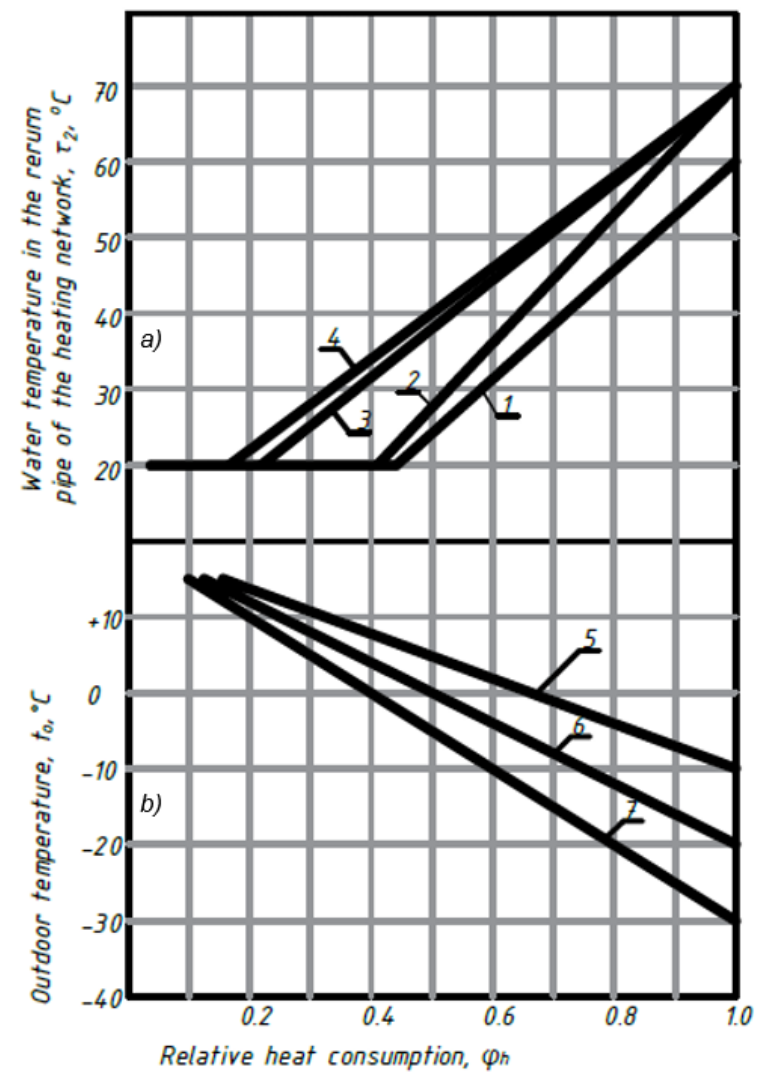

Figure 8. Heat carrier temperature in the return pipe of the heating network (a) and relative heat load for heating (b) vs. external temperature for different temperature schedules of heat supply: $80 / 60^{\circ} \mathrm{C}(1) ; 90 / 70^{\circ} \mathrm{C}(2) ; 115 / 70^{\circ} \mathrm{C}(3) ; 135 / 70^{\circ} \mathrm{C}$ (4), and different design external temperatures: $-10^{\circ} \mathrm{C}(4) ;-20^{\circ} \mathrm{C}(5) ;-30^{\circ} \mathrm{C}(6)$, with central flow rate control 
ensure additional savings in the form of a reduction in energy consumption for heat carrier pumping.

Fig. 9 shows the results of calculating the flow rate of network water with combined control of heat load in comparison with traditional quality control. The connected heat load is $100 \mathrm{MW}$, and the design external temperature is $-23^{\circ} \mathrm{C}$.

Between points $A$ and $B$, quality control is carried out. At an external temperature of $-8^{\circ} \mathrm{C}$, the temperature curve is characterized by a breakpoint and it is proposed to switch from quality to flow rate control. This makes it possible to reduce the flow rate of the heat carrier along the B-f-F line.

This, in turn, creates conditions for a significant reduction in energy consumption for network water transportation, which is shown in Fig. 10. It graphically represents an analysis of the required power of network pumps for several options of central heat load control.

The $a-b-c-e-d$ line represents power consumption by network pumps for the current state, i.e., the dependent circuit for the connection of multi-story buildings and central heat load quality control.

The A-B-C-E-D line shows how power consumption by pumps will change after they are replaced with more modern ones (without changing the consumer connection diagram and the control method).

The A-B-f-E-D line shows how power consumption will change when switching to combined central control according to the method proposed in the paper.

The 1-2-3-4-5 line represents the results of the analysis of changes in the power of network pumps at combined central control when switching to an independent circuit for connection of heat consumers.

The results of the analysis show that the transition to the combined central control of heat supply and changes in the method of connecting multi-story buildings can significantly reduce the power of the electric motors of network pumps. This, in turn, reduces fuel consumption for energy generation as well as environmental pollution by harmful substances from the combustion products (JantaLipińska, 2020).

The flow rate stage of combined heat load control (along the B-E or 2-3 lines, Fig. 10) requires the installation of automatic drive speed controllers on network pumps, which, in turn, requires significant investments. As an intermediate option, it is proposed to install several pumps (instead of one network pump) with a common flow equal to the replaced one (for instance, three pumps with a capacity equal to $1 / 3$ of the current one). Analysis of the annual heat consumption schedule will make it possible to select the number and specifications of new pumps more accurately. To provide summer load, another pump with the corresponding flow is required. These pumps, running at a constant speed, will be connected in parallel and switched on automatically, depending on the external temperature. This will mean a stepwise implementation of the flow rate stage of combined heat load control.

\section{Consumer connection optimization}

Equipping heat consumers with modern automated IHSs with weather control and the corresponding transition to central flow rate or combined control at the heat sources shall be considered as a long-term perspective of $\mathrm{CHN}$ development. This will require the installation of automatic drive speed controllers on network pumps and changes in the thermal-mechanical scheme of boiler rooms.

It will also be necessary to optimize the heat output of boiler units in accordance with the connected heat load and the annual heat

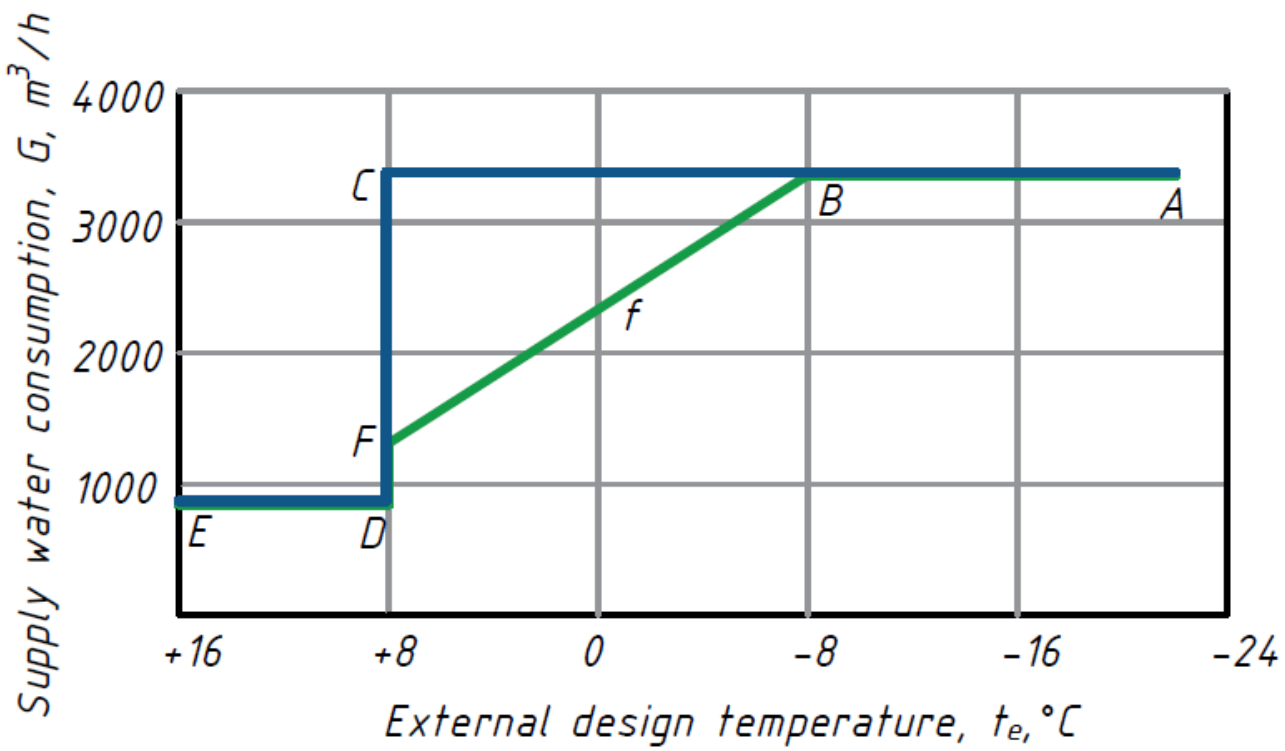

Figure 9. Heat carrier flow rate in the $\mathrm{CHN}$ vs. external temperature: $A-C-D-E$ with quality control; A-B-f-F-D-E - with combined control 
consumption schedule. Such modernization of boiler houses shall prevent an excessive decrease in the flow rate of the heat carrier circulating through the boilers. From this perspective, even in the case of hot water boilers, it is preferable to separate the boiler and heating network circuits according to the known schemes.

The main obstacle to the introduction of automated IHSs and central flow rate or combined control is not only in the unreadiness of energy sources. The complete transition to such control can be carried out only after the introduction of an independent connection circuit or automated IHSs with mixing units in all buildings. However, this requires significant investments and time.

Therefore, buildings with obsolete IHSs will remain in the $\mathrm{CHN}$ for a long time. This may disturb the hydraulic and thermal stability of end-user heating systems in such buildings. Inevitable changes in pressure difference and flow rate difference at the points of connection to the heating network will be the reason for temperature stratification. The proposed solutions imply significant changes in the flow rate of the network heat carrier.

As an intermediate option, it is proposed to ensure local group control at central (group) heat stations. Until all buildings are fully equipped with automated IHSs, their reconstruction will make it possible to switch to more efficient quality and flow rate local control of heat supply, eliminating inefficient heat losses associated with excessive heating.

Fig. 11 shows a schematic diagram of the reconstruction of a central heat station for the transition to quality and flow rate group control of heat supply in the absence of automated IHSs in the connected buildings.

The reconstruction implies equipment of the central heat station with mixing units, which will ensure constant water consumption in the distributing four-pipe heating network after the connection point. This will prevent the hydraulic and thermal deregulation of end-user systems in the buildings connected to the central heat station.

With such a scheme, the heat flow for heating can vary depending on the ratio between the heat extraction for heating and heat extraction for hot water supply. In short periods of maximum heat extraction for hot water supply, the heat flow for heating will decrease. However, after the end of the peak water draw-off, the heat deficit for heating will be compensated for (Orłowska, 2020).

The annual indicators of the efficiency related to the implementation of such control were calculated for the previously mentioned parameters: heat load of $100 \mathrm{MW}$ and design external temperature of $-23^{\circ} \mathrm{C}$ :

- reduction of inefficient heat losses -18,806 $\mathrm{MWh}(6.4 \%$ of the annual heat generation before reconstruction);

- equivalent fuel economy (natural gas) 2.304 million $\mathrm{m}^{3}$;

- energy saving - $2451 \mathrm{MWh}$ (41\% of energy consumption during the period corresponding to the breakpoint of the temperature curve before reconstruction);

- corresponding reduction of $\mathrm{CO}_{2}$ emissions 6426 tons.

\section{Conclusions}

1. Central quality control in the conditions of

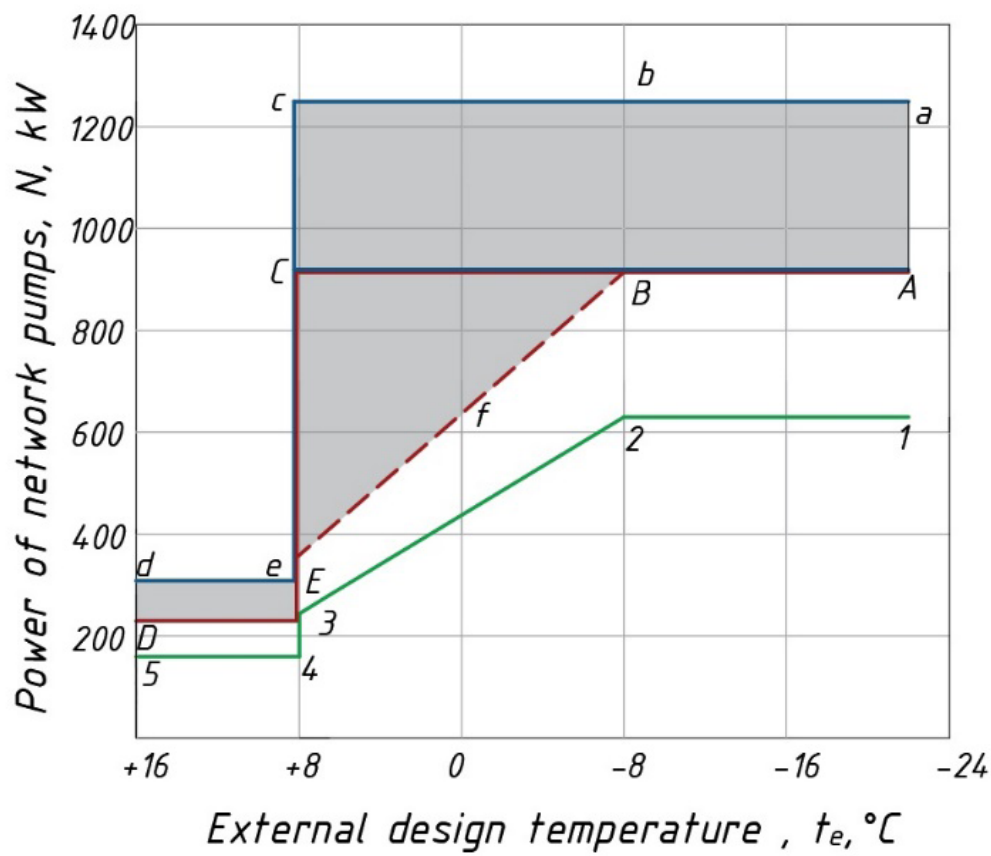

Figure 10. Power of network pumps in the heating network vs. external temperature (the corresponding options are described in the text) 


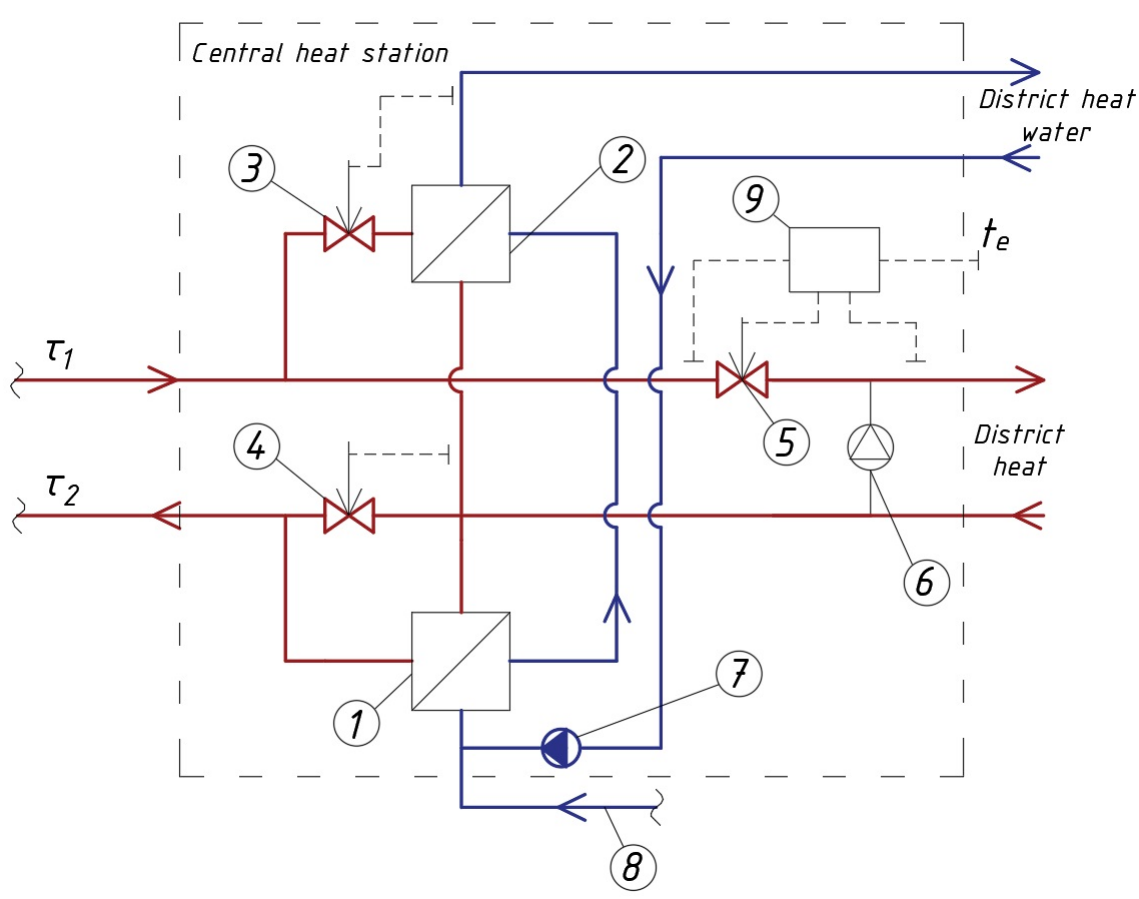

Figure 11. Schematic diagram of the reconstruction of a central heat station for the implementation of quality and flow rate local control of heat supply for heating: 1 - first-stage hot water supply heat exchanger; 2 - second-stage hot water supply heat exchanger; 3,4 - hot water temperature controllers; 5 - controller of the heat carrier flow rate for heating; 6 - mixing pump with rpm control; 7 - hot water supply circulating pump; 8 - cold water pipe; 9 - controller

equipping end-user systems with automated IHSs, transition to a low-temperature schedule of heat supply, and the lack of condensing waste heat exchangers at the energy sources is characterized by low efficiency and significant disadvantages. The main disadvantage is significant heat losses during the transition periods corresponding to the breakpoint of the temperature curve. Such heat losses reach $18 \%$ of the thermal potential of the used fuel. Another disadvantage is inevitable constant changes in the flow rate of the heat carrier in heating networks, which are caused by local quality control of heat supply in automated IHSs.

2. It is proposed to introduce combined control, which, before reaching the breakpoint temperature, ensures quality control of heat supply by changing the heat carrier temperature only. After the corner point, the transition to central flow rate control is performed by changing the flow rate of the heat carrier at its constant temperature.

3. Combined central control makes it possible to prevent significant heat losses as well as hydraulic and thermal deregulation of local systems and provide optimal conditions for heat generators, including in condensing mode. It also reduces energy consumption and increases the overall efficiency of the $\mathrm{CHN}$.

4. The possibility of a complete transition to flow rate control in the entire range of changes in the heat load has been substantiated. Such control is very important for $\mathrm{CHNs}$ due to the ongoing thermal modernization of buildings and their equipping with automated IHSs.

5. During the transition period, for buildings connected to the $\mathrm{CHN}$ according to a dependent scheme without mixing units and automatic weather control, a combination of combined central control with local quality and flow rate control in group central heat stations is recommended.

6. Central combined and flow rate control have certain disadvantages, e.g., variable hydraulic operation of heating networks. However, with the introduction of a low-temperature schedule of heat supply, such control is characterized by significant advantages. 


\section{References}

Bhatt, J. and Verma, H. K. (2015). Design and development of wired building automation systems. Energy and Buildings, Vol. 103, pp. 396-413. DOI: 10.1016/j.enbuild.2015.02.054.

Bogoslovsky, V. N. and Skanavi, A. N. (1991). Heating. Moscow: Stroyizdat, 735 p.

Chicherin, S. V. (2018). Optimization of thermal energy consumption by buildings: diagrams of changes in the load on weekdays and weekends. In: Proceedings of the International Conference "Sustainable and Efficient Use of Energy, Water and Natural Resources”, November 12-16, 2018, Tomsk. Tomsk: Publishing House of Tomsk Polytechnic University, pp. 58-60.

Chicherin, S., Volkova, A. and Latõšov, E. (2018). GIS-based optimisation for district heating network planning. Energy Procedia, Vol. 149, pp. 635-641. DOI: 10.1016/j.egypro.2018.08.228.

Cui, M., Wang, X. and Liu, J. (2014). The analysis of plate heat exchanger in central heating regulation of indirect connection hot water heating system. Applied Mechanics and Materials, Vols. 584-586, pp. 728-731. DOI: 10.4028/www.scientific. net/AMM.584-586.728.

European Parliament and Council (2018). Directive (EU) 2018/2001 of the European Parliament and of the Council of 11 December 2018 on the promotion of the use of energy from renewable sources (recast) (Text with EEA relevance). Official Journal of the European Union, OJ L 328 21.12.2018.

Janta-Lipińska, S. (2020). The method of nitrogen oxide emission reduction during the combustion of gaseous fuel in municipal thermal power boilers. Rocznik Ochrona Środowiska, Vol. 22, Part 1, pp. 376-390.

Kultyaev, S. G. (2017). Comparative analysis and optimization of methods for regulating the combined heat load. Naukovedenie, Vol. 9, No. 2. [online] Available at: http://naukovedenie.ru/PDF/61TVN217.pdf [Date accessed December 10, 2018].

Logunova, O. Ya. and Zorya, I. V. (2020). Water heating. $2^{\text {nd }}$ edition. Saint Petersburg: Lan, 272 p.

Lund, H., Østergaard, P. A., Chang, M., Werner, S., Svendsen, S., Sorknæs, P., Thorsen, J. E., Hvelplund, F., Mortensen, B. O. G., Mathiesen, B. V., Bojesen, C., Duic, N., Zhang, X. and Möller, B. (2018). The status of $4^{\text {th }}$ generation district heating: Research and results. Energy, Vol. 164, pp. 147-159. DOI: 10.1016/j.energy.2018.08.206.

Magnusson, D. (2011). Between municipal and regional planning: the development of regional district heating systems in Stockholm from 1978 to 2010. Local Environment, Vol. 16, Issue 4, pp. 319-337. DOI: 10.1080/13549839.2011.573472.

Orłowska, M. (2020). Experimental research of temperature distribution on the surface of the front plate, of a flat plate heat exchanger. Rocznik Ochrona Środowiska, Vol. 22, pp. 256-264.

Pieper, H., Ommen, T. S., Markussen, W. B. and Elmegaard, B. (2017). Optimal usage of low temperature heat sources to supply district heating by heat pumps. In: Proceedings of ECOS 2017: 30th International Conference on Efficiency, Cost, Optimization, Simulation and Environmental Impact of Energy Systems, July 2-6, 2017, San Diego, CA, USA, article \#30. San Diego: San Diego State University.

Rafalskaya, T. A., Mansurov, A. R. and Mansurova, A. R. (2019). Investigation of variable modes of centralized heat supply systems operation with qualitative and quantitative regulation. Construction and Geotechnics, Vol. 10, No. 2, pp. 79-91. DOI: 10.15593/2224-9826/2019.2.07.

Rafalskaya, T. A., Rokhletsova, T. L. and Tyusov, S. M. (2018). Central regulation without upper cut: capabilities and prospects. News of Higher Educational Institutions. Construction, No. 5 (713), pp. 91-104.

Sharapov, V. I. and Rotov, P. B. (2007). Heat supply system load control. Moscow: Novosti Teplosnabzheniya, 164 p.

Sharapov, V. I., Rotov, P. V. and Orlov, M. E. (2010). The improvement technologies of the thermal load regulation for cogeneration systems in urban areas. Transactions of Academenergo, No. 4, pp. 70-83.

Sokolov, Ye. Ya. (1982). Heat and power supply and heating networks. $5^{\text {th }}$ edition. Moscow: Energoizdat, $360 \mathrm{p}$.

Szkarowski, A. (2019). Ciepłownictwo. Wydanie III uaktualnione. Warszawa: Wydawnictwo Naukowe PWN, 344 p.

Szkarowski, A., Janta-Lipińska, S., Koliienko, A. and Koliienko, V. (2016). Poprawa sprawności scentralizowanych systemów ciepłowniczych przez doskonalenie metod regulacji. Ciepłownictwo, Ogrzewnictwo, Wentylacja, Vol. 47, No. 9, pp. 347-351. DOI: 10.15199/9.2016.9.1. 


\title{
ПОВЫШЕНИЕ ЭФФЕКТИВНОСТИ РЕГУЛИРОВАНИЯ ТЕПЛОВОЙ НАГРУЗКИ В СИСТЕМАХ ЦЕНТРАЛИЗОВАННОГО ТЕПЛОСНАБЖЕНИЯ
}

\author{
Александр Леонидович Шкаровский ${ }^{1,2 *}$, Анатолий Григорьевич Колиенко ${ }^{3}$, Виталий Сергеевич Турченко ${ }^{3}$ \\ ${ }^{1}$ Санкт-Петербургский государственный архитектурно-строительный университет \\ 2-ая Красноармейская ул., 4, Санкт-Петербург, Россия \\ ${ }^{2}$ Кошалинский Технологический университет, \\ ул. Снядецких, 2, Кошалин, Польша \\ ${ }^{3}$ Национальный университет «Полтавская политехника имени Юрия Кондратюка» \\ Першотравневий проспект, 24, Полтава, Украина \\ *E-mail: szkarowski@mail.ru
}

\begin{abstract}
Аннотация
В статье представлены результаты исследований, целью которых является повышение эффективности систем централизованного теплоснабжения путем совершенствования процессов центрального и местного регулирования отпуска теплоты. Для этого комплексно рассмотрены задачи выбора оптимального графика отпуска теплоты и его влияния на эффективность выработки, транспортировки и использования теплоты, влияния температуры теплоносителя на потери теплоты в период излома температурного графика. Исследовано влияние температуры теплоносителя в обратном трубопроводе тепловых сетей на работу генераторов теплоты при различных способах регулирования. Рассмотрена задача обеспечения гидравлической и тепловой устойчивости работы тепловой сети и подключенных к ней систем отопления в условиях комбинированного способа регулирования. В основу методологии работы положено исследование уравнений теплового баланса для установившегося стационарного режима работы комплекса, включающего тепловую сеть и систему отопления здания. Получены зависимости, которые дают возможность определить изменение расхода и температуры теплоносителя в зависимости от тепловой нагрузки, а также сокращение расхода электрической энергии на транспортировку теплоносителя. Разработаны рекомендации по внедрению комбинированного регулирования тепловой нагрузки и предложена схема реконструкции центральных тепловых пунктов. Научные и практические результаты работы дают возможность избежать значительных потерь теплоты, обеспечивают оптимальные условия работы тепловых сетей, генераторов теплоты и систем отопления, обеспечивают снижение расхода электроэнергии и повышение общей эфффективности систем централизованного теплоснабжения.
\end{abstract}

\section{Ключевые слова}

Теплоснабжение, централизованные системы, экономия энергии, эффективность, регулирование тепловой нагрузки. 